\title{
鉛直過荷重時における鋼構造立体剛接骨組の不安定挙動 UNSTABLE BEHAVIOR OF SPATIAL RIGID STEEL FRAME SUBJECTED TO OVER LOAD
}

\author{
村本＼cjkstart真*，金尾伊 織**, 森迫清 貴*** \\ Makoto MURAMOTO, Iori KANAO and Kiyotaka MORISAKO
}

\begin{abstract}
Collapse behavior of spatial rigid steel frame while vertical load at one place of the beam continues to increase gradually is investigated experimentally and numerically. The spatial frame consists of four columns and four beams. Lateral buckling of the $\mathrm{H}$-shaped beam induced the collapse of frame. The tips of both square tube columns supporting the beam were drawn inward. The center of the beam was twisted and at the portion the plastic hinge was formed by weak axis bending. The torsion or sway behavior of frame was hardly observed in this study. The experimental results of small steel frames are illustrated that the numerical prediction by the elasto-plastic beam-column FEM developed by the authors has adequate precision.
\end{abstract}

Keywords : Spatial rigid steel frame, Over load, Frame instability, Lateral buckling, Elasto-Plastic Beam-Column FEM 立体剛接骨組, 過荷重, 骨組不安定, 横座屈, 弾塑性梁-柱有限要素法

\section{1.はじめに}

ドームやトラス構造においては，想定以上の鉛直過荷重時の安全 性に関して注意深く検詂え代, 1) 3) されている.ラーメン骨組にお いても，例えば施工時の偏荷重や，多雪区域における積雪荷重の変 化によって，梁に鉛直方向に過大の荷重を受ける状況も考えられる. また，建築の一部に吹き抜けを設けたり，建築空間の開放性や構造 躯体の軽快さを見せようとする意匠的要求から比較的細長比の大き な柱を多用する建築となることもある。細長い部材を用いた開放的 な空間を有する骨組においては，座屈や大たわみなどが立体的なね じれ挙動を誘発したり, 骨組の sway などの不安定挙動を生じさせる 可能性が考えられる，それ故，鋼構造立体ラーメン骨組の鉛直過荷 重時における骨組の全体挙動を崩壊に至るまで把握しておくことは, 安全性の議論の上で重要である.

鋼平面骨組を対象として，中村・太田・上谷により，局所的な鉛 直過荷重を受ける小型鋼骨組模型の実験 ${ }^{4)}$ が行われている。また, 中村・石田・太田によって同様の鉛直過荷重を受ける骨組の数值解 析的研究 ${ }^{5)}$ も実験に先行して行わ机ている。しかしながら，鉛直過 荷重時における立体骨組を対象とした既往の研究は，ほとんど見あ たらない.

筆者らは，立体骨組としてのふるまいに着目し，単層立体骨組の 柱頭および梁中央に局所的過荷重を受ける構造物の挙動を文献 6）に
おいて数值解析を用いて調べた。そこでは，載荷位置と柱脚の固定 度の違いにより最終的に骨組不安定が誘発されることを示した。

本論では，まず小型立体骨組実験を行い，数值解析による実験の 予測性を検討する。 その後, 鉛直過荷重時における鋼構造立体ラー メン骨組の不安定挙動を数值解析によって検討する.

\section{2、鋼構造小型立体骨組による実験}

小型立体骨組による実験は，1層 1 スパンの骨組を対象とし，梁一 力所の鉛直載荷である。ただし, 載荷位置を梁中央に設けたもの（試 験体 1）と梁中央より偏心させたもの（試験体 2）の 2 つについて行つ た，実験対象骨組の製作にあたっては，事前に増分摂動法による立 体梁-柱有限要素法 FERT-3P ${ }^{7)}$ によって数值解析を行った情報をも とに骨組寸法，部材寸法を決定した。

実験は，載荷される梁の大変形によって両側柱の引き込み現象を 確認すること，解析法の性能検証を行うことを目的とする基礎的実 験と位置づけた。また, 試験体 2 によって, 荷重偏心が骨組の立体 的挙動を変化させるかどうかを確認する.

\section{1 試験体の製作と載荷ならびに計測方法}

試験体寸法は, 先の事前解析のほか実験室への設置と変位計測計 画の制限に適うように決定した。断面形状については，事前解析を もとに，既製品寸法や京都工芸繊維大学ものづくり教育研究支援セ
* 高知工業高等専門学校建設システム工学科 助教・博士 (学術)

** 京都工芸繊維大学大学院工芸科学研究科造形工学部門 准教授. 博士 (学術)

*** 京都工芸繊維大学大学院工芸科学研究科造形工学部門 教授・博士 (工学)
Asst. Prof., Dept. of Civil Engneering, Kochi National College of Technology, Ph. D.

Assoc. Prof., Dept. of Architecture and Design, Graduate School of Science and Technology, Kyoto Instititute of Technology, Ph. D.

Prof., Dept. of Architecture and Design, Graduate School of Science and Technology, Kyoto Instititute of Technology, Dr. Eng. 
ンターで鋼材の切削加工が可能なサイズを制限として決定した。試 験体の寸法と断面形状は以下の通りである。スパン $500 \mathrm{~mm}$ ，階高 $1000 \mathrm{~mm} ，$ 柱は $\square-9 \times 9 \times 1 ，$ 梁は $\mathrm{H}-10 \times 8 \times 1 \times 1$ である，柱は市販の角 形鋼管を採用し，梁は $10 \times 8$ の鋼角棒から切削加工により製作した. 接合部・載荷部治具は, 藤本らが行った実験 ${ }^{8)}$ を参考に, 鋼塊から 切削・レーザー加工によって製作したもので，柱および梁をスプリ ングワッシャーを介してボルト締めによって固定される。各試験体 は実験毎に組み立て，載荷台の上に設置する。載荷台は，載荷の都 合上，試験体柱脚が床から $1300 \mathrm{~mm}$ の位置となるよう $\mathrm{H}$ 形鋼を用 いて作成した，載荷台と試験体の設置について図 1 に示す。柱脚は, 固定支持となるように接合部と同様の方法で固定した。載荷位置は, 試験体 1 で梁中央とするが, 試験体 2 は, 梁中央から $75 \mathrm{~mm}$ 偏心さ せている。また, 製作した接合部・載荷部治具を図 2 に示す。図 2 は, 治具の見上げ図と立面図で，一部を断面図として示している.

JIS14A，14B に従って，柱と梁の引張試験片を 2 体ずつ製作し, それぞれの材料特性を調べた。材料試験結果を図 3 に，表 1 に実験 から得られた材料特性について, ヤング係数 $E$, 降伏応力度 $\sigma_{y}$, 引 張強さ $\sigma_{u}$ を示す。明瞭な降伏点がない応力ひずみ関係であった。降 伏点の設定にあたっては，通常残留ひずみが $0.2 \%$ となる值を採用す るが，本実験で数值解析コードの性能検証を行うという目的もあり， 表 1 に示す值とした。梁の材料はSS400を予定していたが，材料試

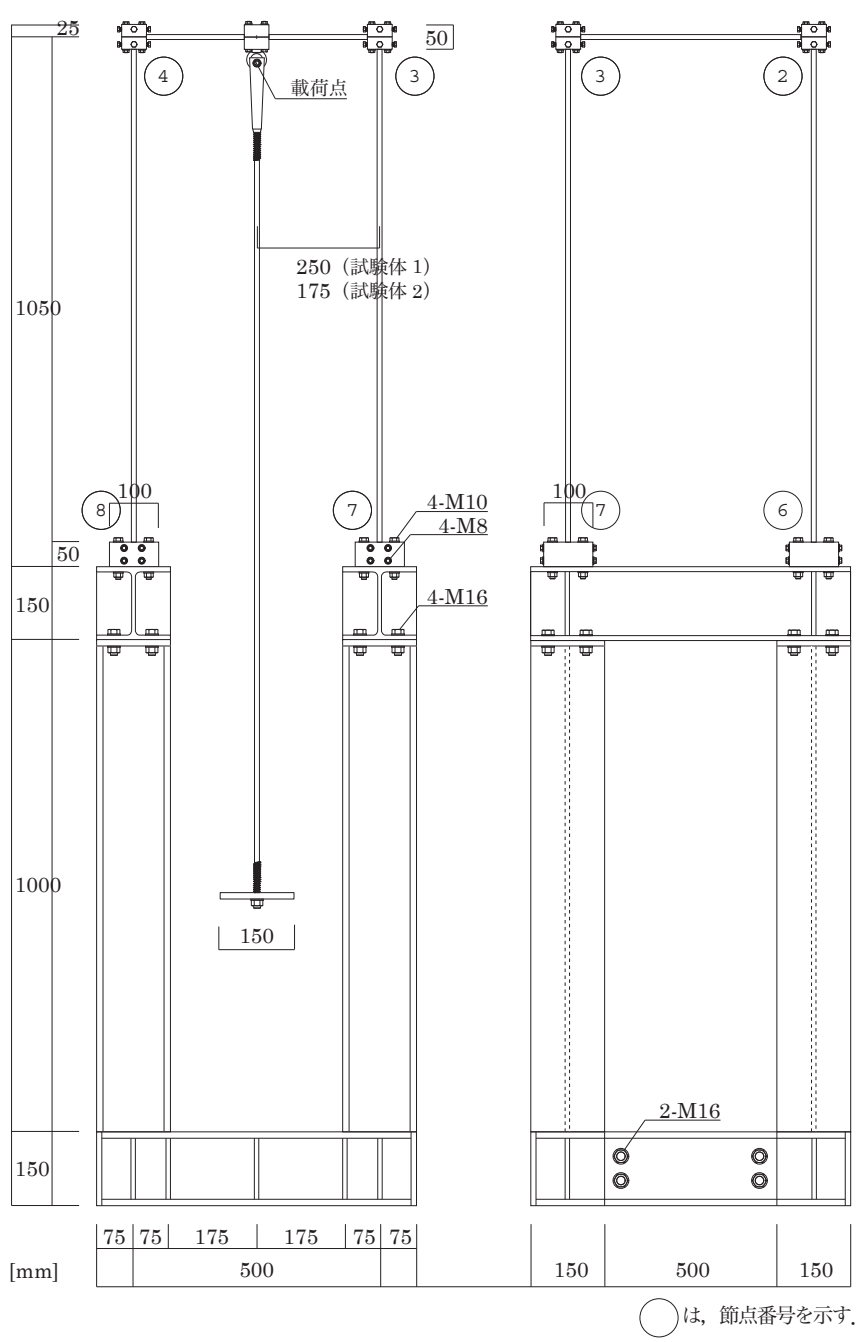

図 1 載荷台と試験体の設置
験の結果から得た降伏応力度 $\sigma_{y}$ が高く, 予定した鋼材とはかなり異 なる。そこで，改めて数值解析を行い，実験が可能であることを確 認した上で実験を実施した。

載荷は，あらかじめひずみを計測することによってキャリブレー ションした M10 のステンレス棒を加工して載荷部治具に接続し，い くつかの種類の鍾を順次載せていく方式で行う。そのため最大荷重 までは計測できるが，荷重が低下する不安定挙動を制御しながら順 次計測することはできない.

変位の計測は，試験体を囲むように設置した計測用フレームに変 位計を設置し，各頂点の変位を 3 方向にそれぞれ計測する，変形が 大きい点は巻き込み変位計を使用し, 変形が比較的小さい点は一般 用変位計, 変位計のワイヤーが交錯して計測が困難な点にはレーザー 変位計を使用した。なお，変位計の配置についても，事前に行った 数值解析結果をもとに決定している. 図 4 には, 計測用フレームの 設置と試験体の節点番号および設定した座標系を示した。なお， Z 軸 は鉛直上向きに設定している。

\section{2 実験結果}

\subsection{1 試験体 1}

図 5 に荷重一変位関係を示す。（a）は載荷点，(b) は載荷点隣りの節
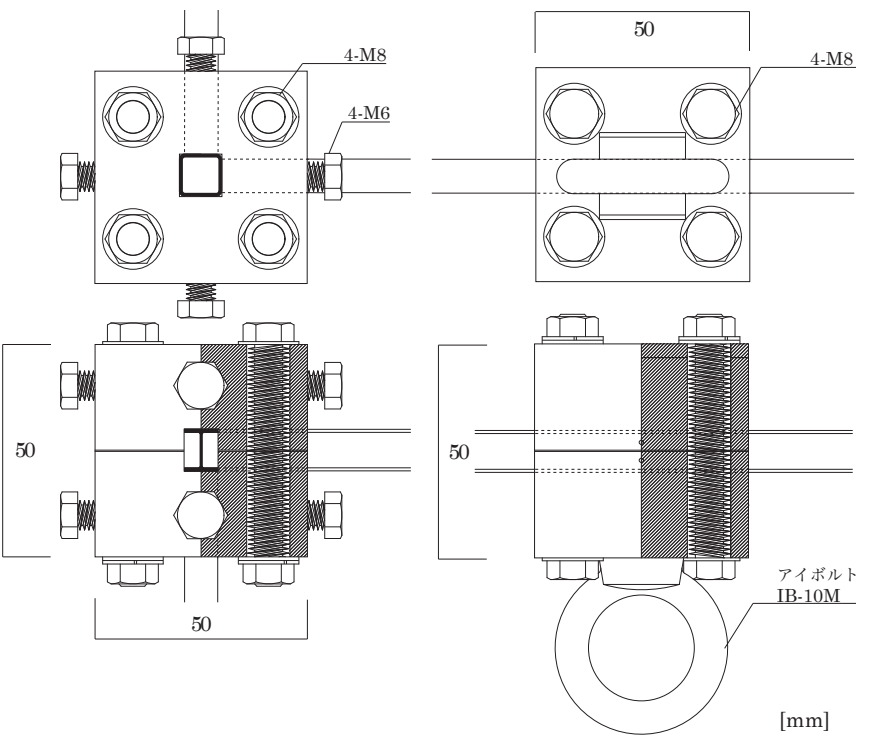

図 2 接合部と載荷部治具

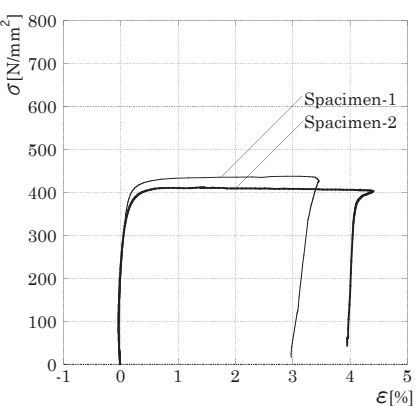

(a) 柱

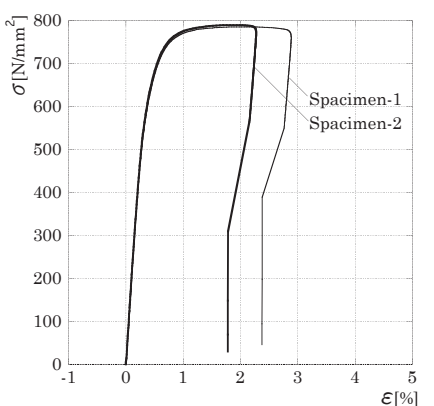

(b) 梁
図 3 材料試験結果

表 1 柱・梁の材料特性

\begin{tabular}{cccc}
\hline & $E\left[\mathrm{~N} / \mathrm{mm}^{2}\right]$ & $\sigma_{y}\left[\mathrm{~N} / \mathrm{mm}^{2}\right]$ & $\sigma_{u}\left[\mathrm{~N} / \mathrm{mm}^{2}\right]$ \\
\hline 柱 & $2.16 \times 10^{5}$ & 400 & 425 \\
梁 & $1.93 \times 10^{5}$ & 750 & 787 \\
\hline
\end{tabular}


点(3)，(c) は鉛直荷重を載荷した梁と反対側の梁の節点(2)の水平およ び鉛直方向変位を示す，載荷点では，鉛直方向変位とX方向変位が 増大していくが, 節点(3)ではY 方向変位のみが大きく増大し, 柱が 内側に引き込まれる様子が計測されている。

載荷点の鉛直下方への急激な変形の増大とともに，直ちに骨組は 崩壊した。このとき，載荷用のステンレス棒の最下部が床面に接地 したので実験を終了した。載荷梁を確認すると，接合部治具のすぐ 横（節点(4)側）で梁下側フランジが破断していた.

写真 1 に，実験終了時の骨組の様子を示す。載荷構面が大きく変 形し，載荷構面両側の柱が載荷点に向かって内側に引き込まれてき ている。また，載荷構面は前に倒れこむようにして変形し，わずかに sway の変形も示している.

\section{2 .2 試験体 2}

試験体 2 は，偏心荷重を与える骨組である，梁中央からの荷重偏 心距離は，載荷台と試験体の位置関係（図 1) から載荷に不都合が生 じないように $75 \mathrm{~mm}$ とした。

図 6 に得られた荷重-変位関係を示す。(a) は載荷点, (b) は節点(3), (c) は節点(2)における変位を示す。最大荷重近傍から徐々に節点(3)が 内側へ引き込まれて行く様子が刻々と計測できている.

試験体 1 では，急激な変形進展の為に崩壊直前の様子を詳しく観 察することができなかったので，試験体 2 では，載荷間隔をおきな がら注意深く観察・計測した。載荷点のたわみ（図 6(a)の UZ）が $2.5 \mathrm{~cm}$ の頃から載荷用鍾の増加によらず徐々に鉛直下方へたわみ続 ける様子を観察することができた。このとき，梁は，載荷点治具と
ともに次第にねじれつつあり，横はらみを増しながら，強軸曲げか ら弱軸曲げに変化するようにねじれていった。その後，試験体 1 と

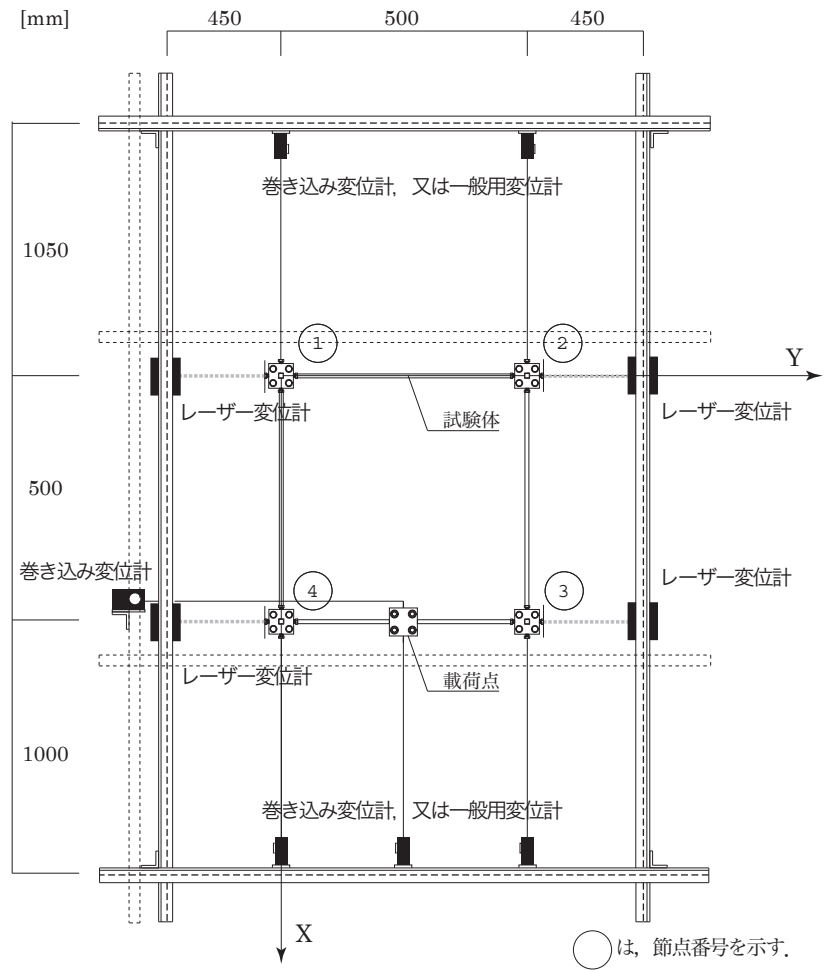

図 4 試験体と計測用フレーム（見下げ図）

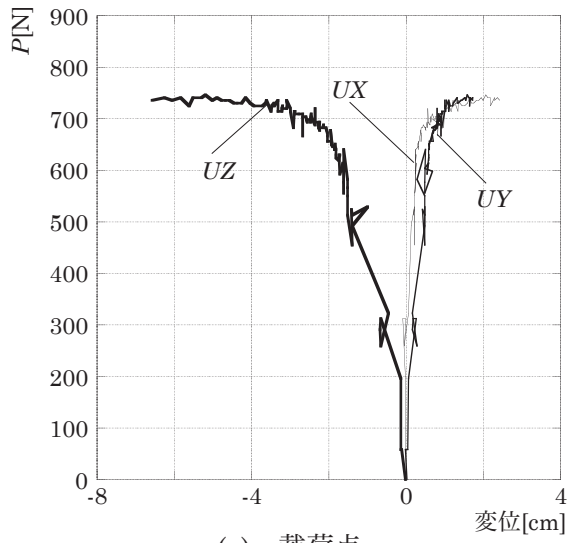

(a) 載荷点

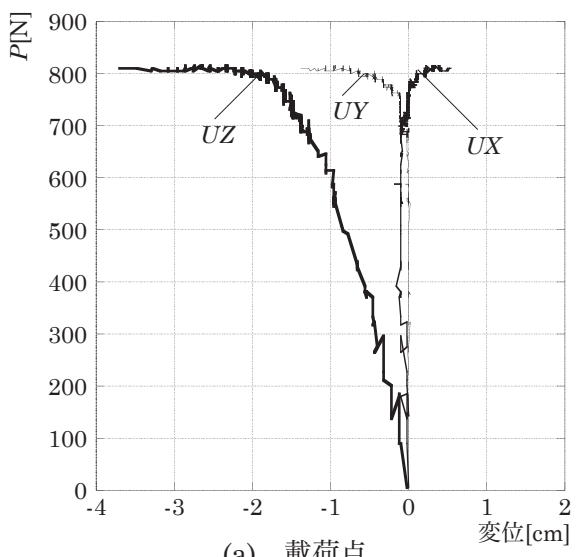

（a）載荷点

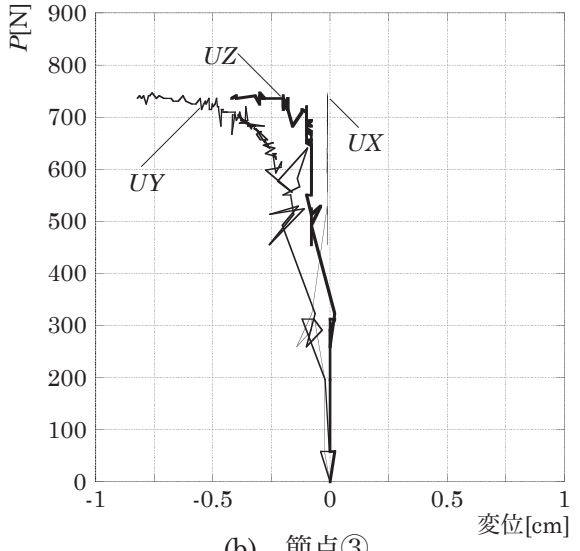

(b) 節点(3)

図 5 試験体 1 の実験結果

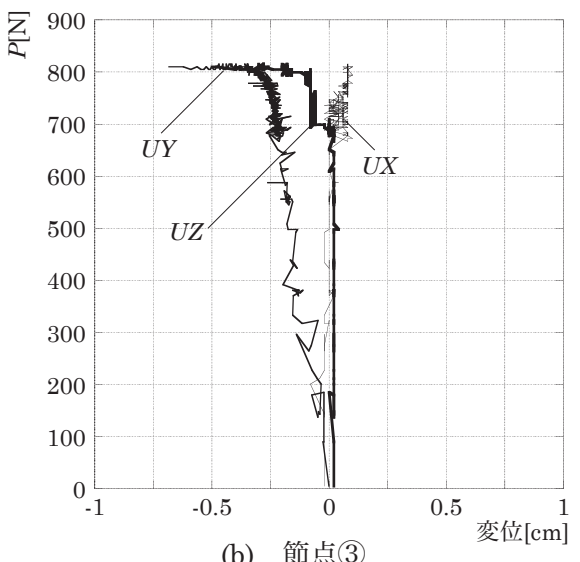

(b) 節点(3)

図 6 試験体 2 の実験結果

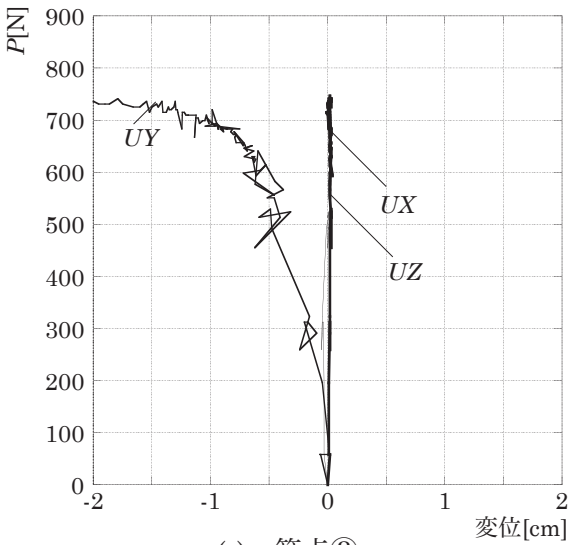

(c) 節点(2)

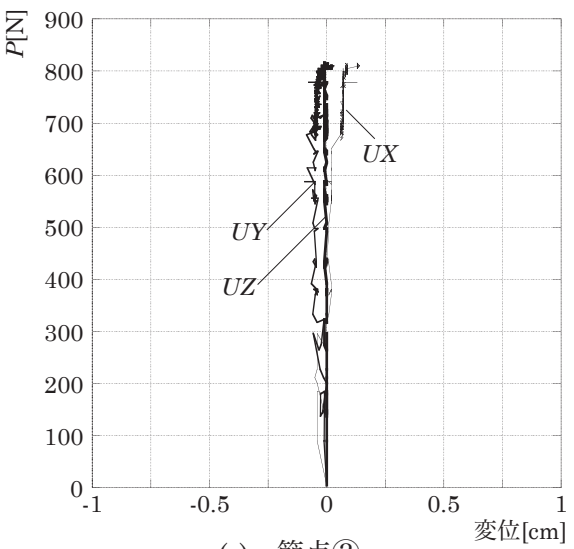

(c) 節点(2) 


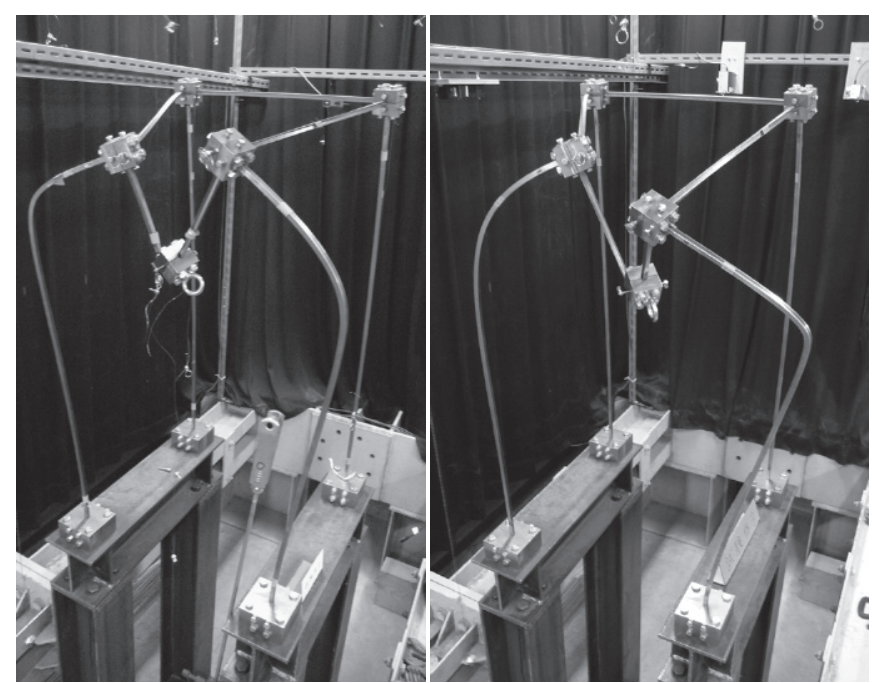

写真 1 試験体 1 の実験最終状況 写真 2 試験体 2 の実験最終状況

同様，載荷用ステンレス棒の最下部が床面に接地したことによって 実験を終了した。

写真 2 に, 実験終了時の最終変形を示す。試験体 2 では，骨組全 体の sway はほとんど生じておらず，骨組は，載荷を受ける梁部材の ねじれによって崩壊している.

$2 つ の$ 試験体から，梁に鉛直過荷重を受ける立体骨組の崩壊挙動を 観察し, 梁の変形進展に伴う両側柱の引き込み現象を確認した。骨 組の終局状態は，梁の横はらみをともなう梁のねじれが原因となっ ての崩壊である。最大荷重は試験体 1 で $746 \mathrm{~N}$, 試験体 2 で $815 \mathrm{~N}$ であった。柱が内側へ引き込まれるため, 平面単純梁の載荷点に七
ンジが形成されるときの崩壊荷重を求めてみると, 試験体 1 では $780 \mathrm{~N}$, 試験体 2 では $908 \mathrm{~N}$ となる。試験体 2 の終局状態の観察から, 梁がねじれて崩壊しており，全くの強軸曲げではなく，そのような 塑性崩壊荷重以前に最大荷重となる。荷重偏心によって崩壊挙動の 様相に違いは，明確には見られなかった。

\section{3. 実験による数值解析法の検証}

ここで，実験結果と事前解析結果を比較する，本論で用いた数值 解析法は, 断面の反りによる垂直応力, 要素に付随する移動座標系 とそ水に伴う有限回転を考慮した座標変換則を採用し，増分摂動法 により定式化された立体骨組解析法 FERT-3P ${ }^{7)}$ である。これまでに, 様々な立体骨組の数值解析 $\left.\left.{ }^{7)}, 9\right) \sim 11\right)$ を試みているが，ここでは，鋼 立体骨組における不安定挙動の追跡性能を検証する。なお，解析法 の詳細については，文献 6)，12）を参照されたい.

\section{1 解析モデルの概要}

図 7 に数值解析モデルを示す. (a) の○内数字は節点番号を示し, $\square$ 内数字は部材番号を示す. 柱 1 本は 4 部材, 梁 1 本は 2 部材として, それぞれ材軸方向に等分割している。

各要素は, 断面積 $A$, 塑性断面係数 $Z_{x}, Z_{y}$, 断面 2 次モーメント $I_{x}, I_{y}$, 反り 2 次モーメント $I_{w}$ とサンブナンの㸚じれ定数 $K$ を一致さ せるように (b) に示す 12 個の集中断面積を持つ材料線要素へと離散 化する。柱と梁の集中断面積, 座標位置と要素分割数について表 2 に示す。

応力ひずみ関係は，(c) に示すバイリニア・モデルに従うものとす る. ヤング係数 $E$, 降伏応力度 $\sigma_{y}$ は材料実験結果から得られた表 1 の值を採用し，ひずみ硬化係数比 $H$ は $1 / 200$ としている．せん断弾 性係数 $G$ は, 解析中一定值とし, ポワソン比 0.3 に対応する值とする.

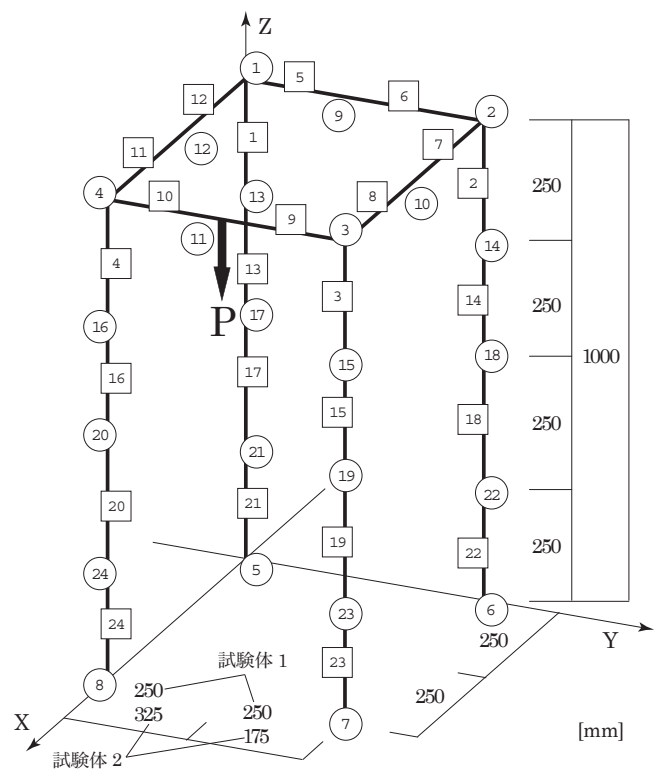

(a) 節点番号と部材番号の設定
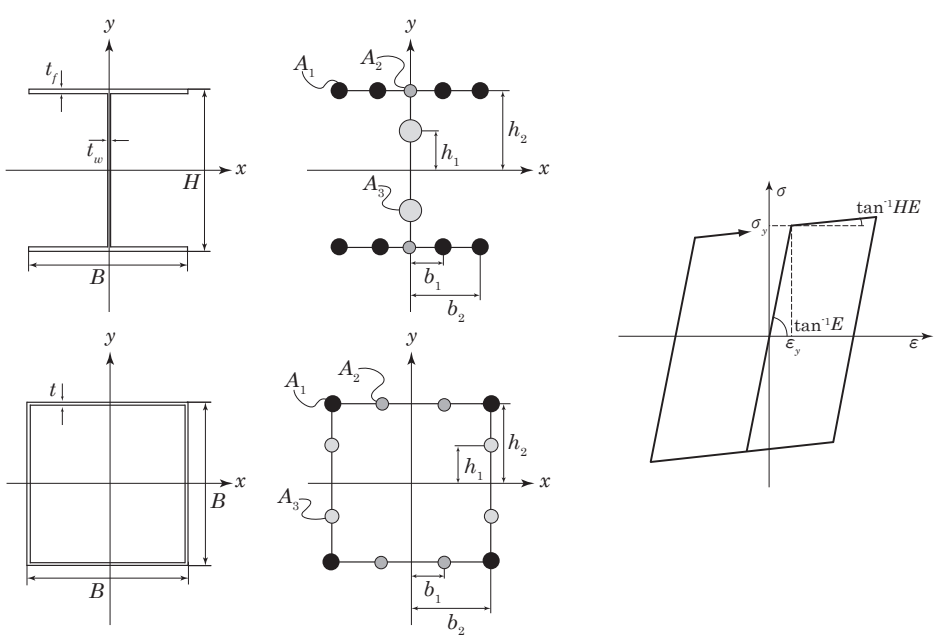

(b) 部材断面のモデル化

(c) 応力ひずみ関係モデル

図 7 数値解析モデル

表 2 部材リスト

\begin{tabular}{|c|c|c|c|c|c|c|c|c|c|c|c|}
\hline & 断面寸法 & $A\left[\mathrm{~mm}^{2}\right]$ & $I_{x}\left[\mathrm{~mm}^{4}\right]$ & $A_{1}\left[\mathrm{~mm}^{2}\right]$ & $A_{2}\left[\mathrm{~mm}^{2}\right]$ & $A_{3}\left[\mathrm{~mm}^{2}\right]$ & $h_{1}[\mathrm{~mm}]$ & $h_{2}[\mathrm{~mm}]$ & $b_{1}[\mathrm{~mm}]$ & $b_{2}[\mathrm{~mm}]$ & 要素分割数 \\
\hline 柱 & $\square-9 \times 9 \times 1$ & 32.0 & 347 & 3.07 & 2.46 & 2.46 & 1.50 & 3.89 & 1.50 & 3.89 & 40 \\
\hline 梁 & $\mathrm{H}-10 \times 8 \times 1 \times 1$ & 24.0 & 368 & 2.00 & 0.100 & 3.90 & 4.80 & 9.30 & 1.69 & 2.81 & 20 \\
\hline
\end{tabular}


接合部および載荷部は, 剛とみなし, 梁と柱の端部それぞれ 1 要素 (要 素長は全て $25 \mathrm{~mm}$ である.）において，ヤング係数 $E$ とせん断弾性 係数 $G$ を他の要素に比べて十分に大きくする.

本論文中での数值解析は，摂動次数を 2 次まで, 計算打ち切り誤 差を $20 \%$ として計算している.

\section{2 実験結果と数值解析}

\section{2 .1 試験体 1}

図 8 に試験体 1 の解析結果と実験結果を示す. (a)〜 (c) は載荷点 の変位を，(d) と (e) は節点(4)の X, Y 方向変位を示す.

事前解析による剛域のみを考慮した解析（Analysis-1）で，弾性 剛性や最大荷重と最大荷重後の劣化の勾配など，数值解析の荷重減 少領域を除いて，実験とほぼ同様の結果を得ている。最大荷重の実 験值は $746.6 \mathrm{~N}$, 解析值は $746.3 \mathrm{~N}$ であった。

また, 若干の不整とモデルの修正を加えた解析 (Analysis-2) を行つ た。実験では，組み立てた試験体の設置後の寸法は確認したものの, 厳密な不整の計測は行っていない, 特に, 組み立て以前に, 梁には, 製作で生じたと思われるいくらかの反りや曲がりが見受けられた。 また，載荷時に載荷点治具の回転を観察している。 そこで，実験結 果を検討し，不整を載荷点 $\mathrm{X}, \mathrm{Y}$ 両方向に $1.0 \times 10^{-2} P$, 材軸方向の回 転自由度に $-1.0 \times 10^{-3} P$ を与えることとした。加えて，載荷点治具の アイボルトを剛体棒 (実長と同じ $47 \mathrm{~mm}$ ) としたモデル化を追加した. その結果，最大荷重は $739.4 \mathrm{~N}$ に低下したものの，全体的な応答は実 験結果により近づいた。

(f) には，解析による解析終了時の変形図 ${ }^{14)}$ を示す。ただし，変形 図のスケールは，節点変位の最大值をもとに自動的に縮尺が決定さ
れる。そのため, 2 つの解析による変形の大きさを直接比較すること はできない. Analysis-2では，載荷点 Y 方向へ不整を加えたため, 節点(3)も同じ方向へ変形する結果となった。一方，Analysis-1の解 析では，写真 1 に記録したような載荷点が大きく変形して梁が内側 に引き込まれ，前傾している様子も確認できる.

いずれの解析でも，変位制御により解析を実行し，最大荷重以降 で載荷梁に横座屈が生じてその方向へ制御が移る.

\section{2 .2 試験体 2}

図 9 に試験体 2 の解析結果と実験結果を示す。(a)〜 (c) に載荷 点を，(d) と (e) に節点(4)の X, Y 方向変位を示した。試験体 1 と同 様に, 剛域のみを考慮した事前解析 (Analysis-1) と, 若干の不整と モデルの修正を加えた解析（Analysis-2）を示した，不整は，載荷 点 X 方向に $-1.0 \times 10^{-2} P, Y$ 方向に $1.0 \times 10^{-2} P$, 材軸方向の回転自由度

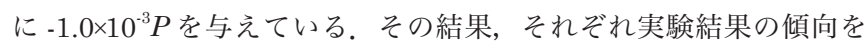
Analysis-1 に比べてょく予測できている. 実験における最大荷重は, 815.5N, Analysis-1 の解析では781.3N，不整を加えた Analysis-2 の解析では $791.4 \mathrm{~N}$ となった。

(f) には, 写真 2 に対応する, 数值解析により得た解析終了時にお ける変形図を示した。ただし, 変形図のスケールについては, 試験 体 1 と同様であり，解析毎に縮尺が異なる.

実験で観察された梁のねじれについては，解析によつても最大荷 重以降にねじれ回転角が急増する様子が捉えられている。これを図 10 に示した.

以上， 2 つの試験体の実験における数值解析から, 筆者らが提案し ている数值解析プログラムの弾塑性不安定挙動に対する予測は, 最

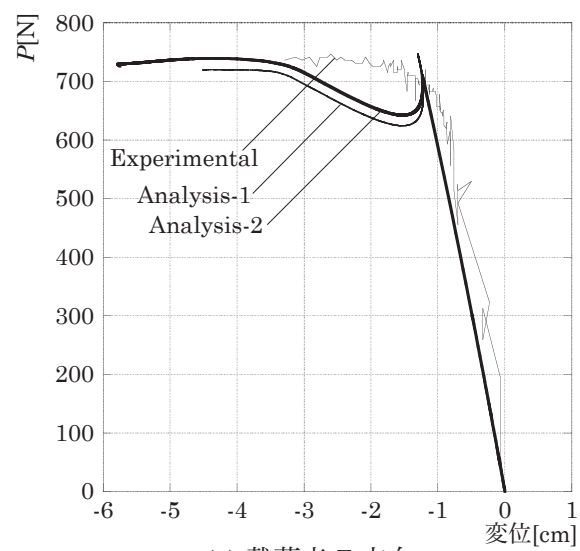

（a）載荷点 Z 方向

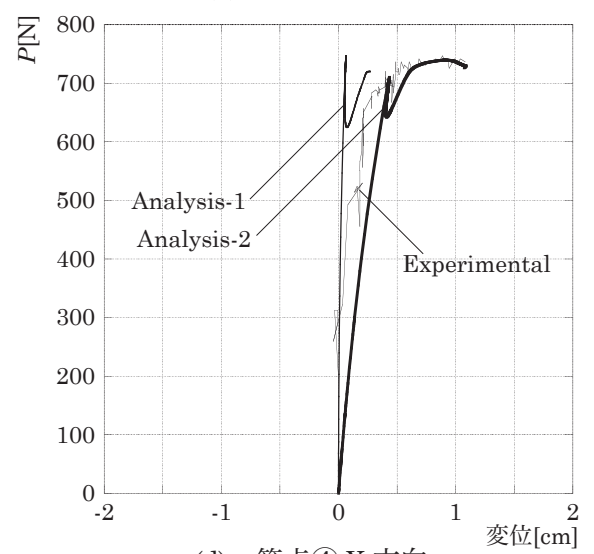

(d) 節点(4) X方向

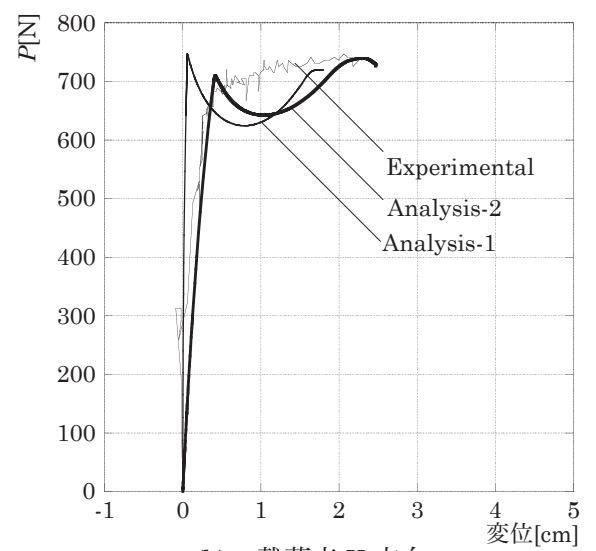

(b) 載荷点 X 方向

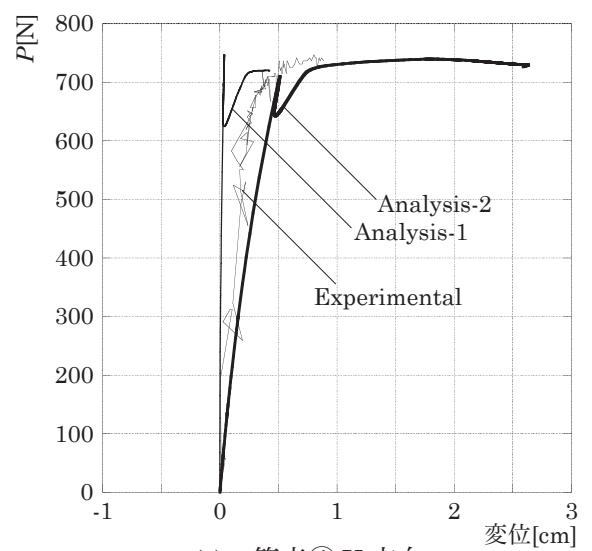

(e) 節点(4) $\mathrm{Y}$ 方向 図 8 試験体 1 の解析結果

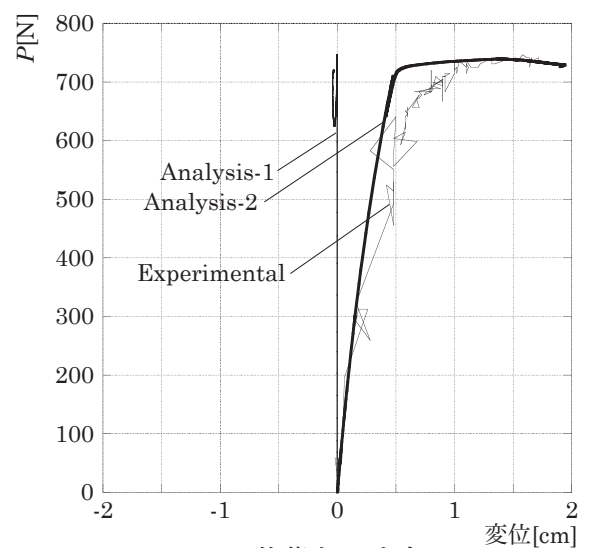

（c）載荷点 $\mathrm{Y}$ 方向

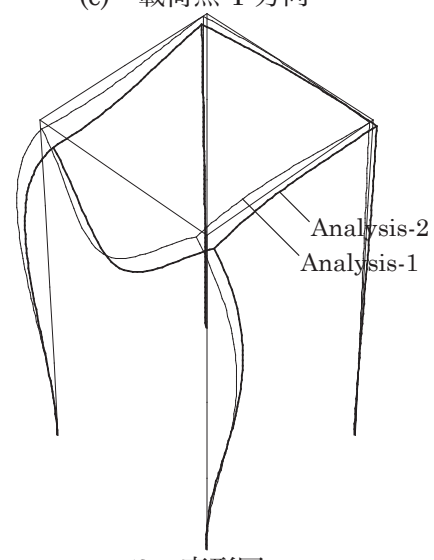

(f) 変形図 


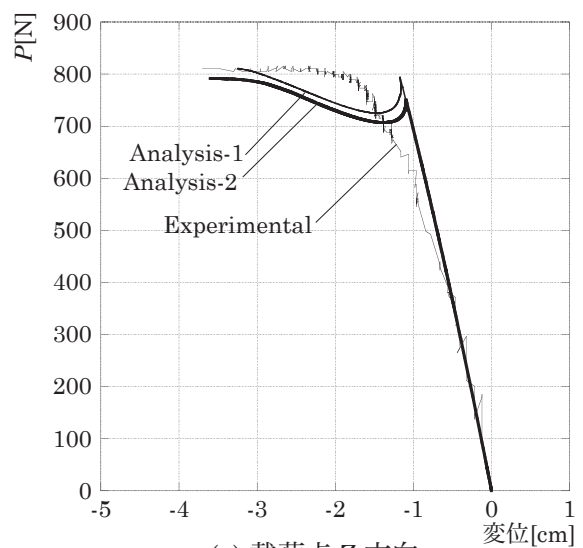

(a) 載荷点 $\mathrm{Z}$ 方向

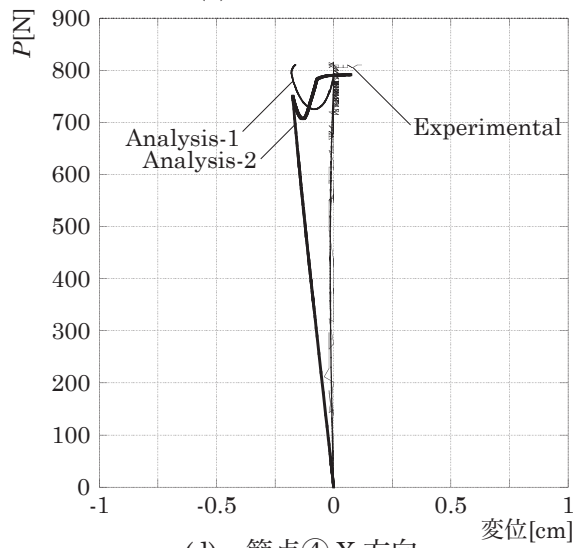

(d) 節点(4) X 方向

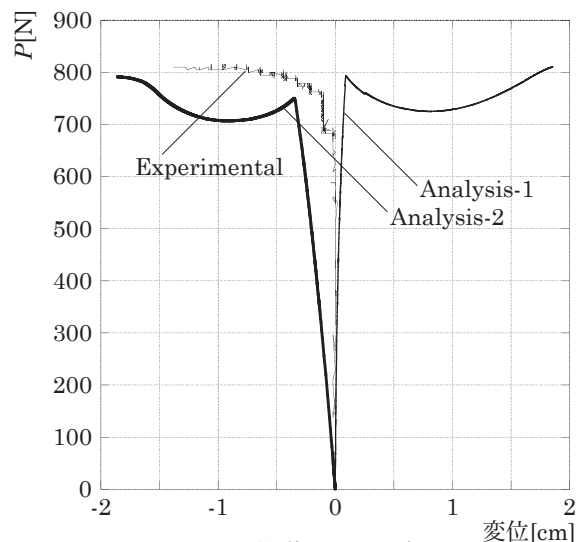

(b) 載荷点 X方向

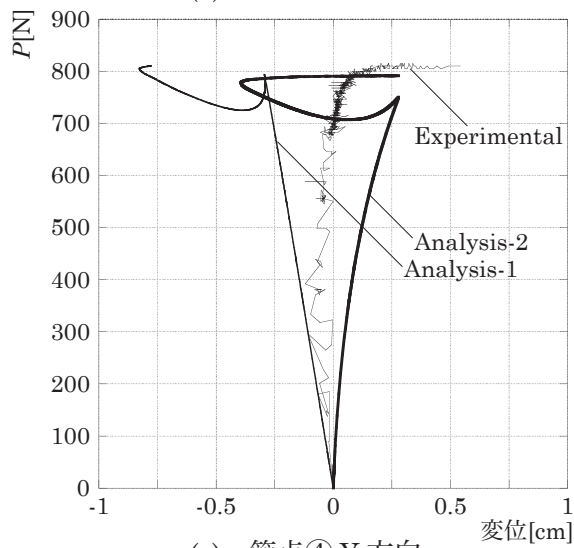

(e) 節点(4) Y 方向

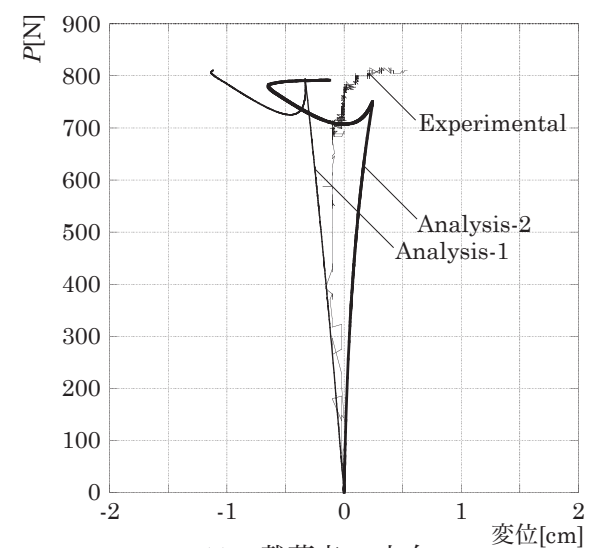

(c) 載荷点 $\mathrm{Y}$ 方向

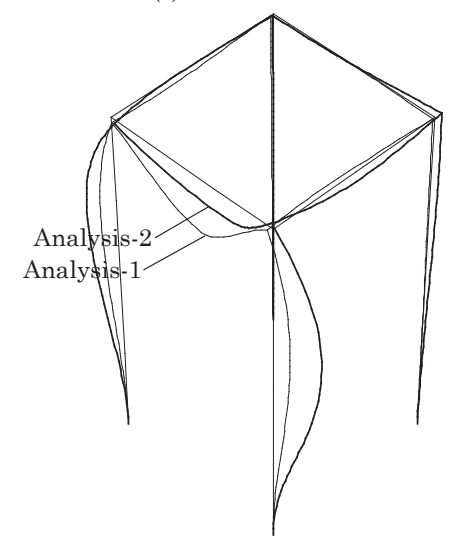

(f) 変形図

図 9 試験体 2 の解析結果

大荷重についてはほぼ予測可能であり, 立体骨組全体の変形挙動に ついてもおおむね予測できることが確認された。

\section{4. 鉛直過荷重時における鋼立体骨組の不安定挙動の解析}

実験で観察したような不安定挙動は，実際の部材を採用した立体 骨組を対象とした場合に生じるか否かについて検討する。梁に局所 的鉛直過荷重を受ける鋼立体骨組の不安定挙動を, いくつかのパラ メー夕を変化させ，これを数值解析により調べる。

ここで対象とする骨組は，文献 6）と同じものを採用する，骨組 形状は，スパン $7 \mathrm{~m}$, 階高 $3.5 \mathrm{~m}$ である，柱脚は固定である．柱の鉛 直荷重として, 屋根の積載荷重 $1.8 \mathrm{kN} / \mathrm{m}^{2}$, 躯体や仕上げ等の固定荷 重 $7.0 \mathrm{kN} / \mathrm{m}^{2}$ から算出される屋根荷重を, 柱頭に 4 等分して与える.
柱頭に与える鉛直荷重は，それぞれ $107.87 \mathrm{kN}$ である，なお，以下 の解析では床スラブ等の合成効果は考えない，部材は，柱が $\square-300 \times$ 300×16, 梁は H-350×250×9×14 からなる. 仕口接合部は剛であるとし， 仕口接合部や剛域は考慮しない.

柱と梁の部材長 $3.5 \mathrm{~m}$ を 15 分割を目安として均等な有限要素に分 割する。 また, 各要素は, 柱を 12 個, 梁を 10 個の集中断面積を持 つ材料線要素へと離散化する。応力ひずみ関係は, バイリニア・モ デルに従うものとする。 ヤング係数 $E$ は $2.05 \times 10^{5} \mathrm{~N} / \mathrm{mm}^{2}$, せん断弾 性係数 $G$ は $0.79 \times 10^{5} \mathrm{~N} / \mathrm{mm}^{2}$, 降伏応力度 $\sigma_{y}$ は $235 \mathrm{~N} / \mathrm{mm}^{2}$, ひずみ 硬化係数比 $H$ は $1 / 100$ とした。なお，せん断弾性係数は，解析中一 定として変化させないものとする.

この単層立体骨組を基本モデルとして, 以下では骨組崩壊に至る

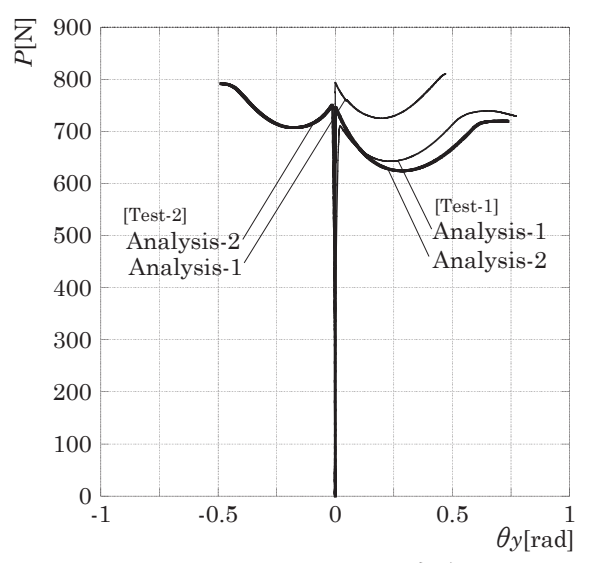

図 10 梁のねじれ回転角

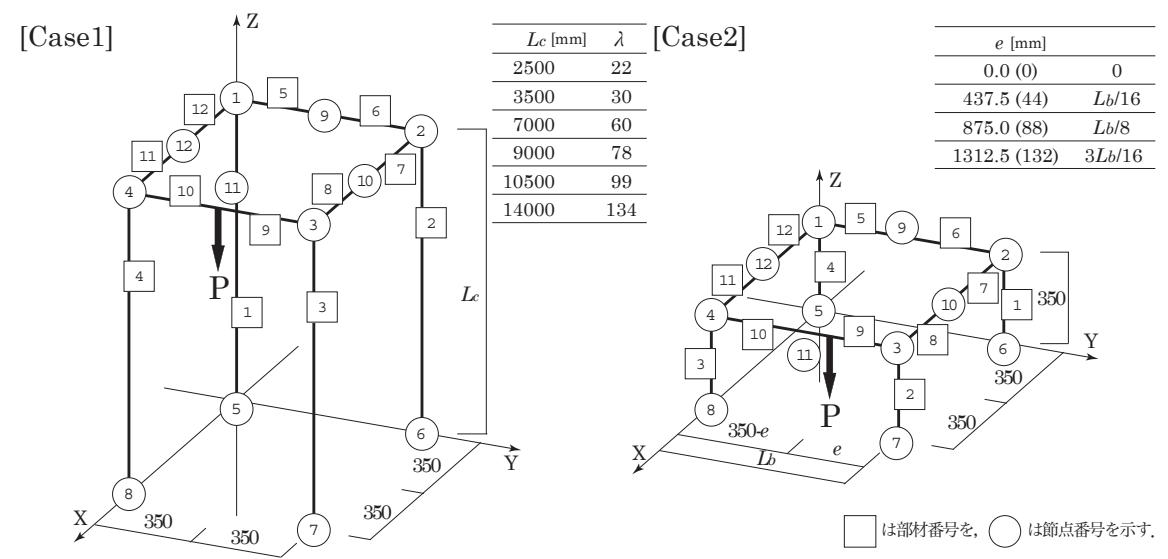

図 11 数值解析モデル 
挙動の変化に着目して,

[Case1]：骨組幾何形状（柱の細長比）の異なる場合,

[Case2]：荷重に偏心がある場合,

の 2 つを考元，以下に検討する.

図11に, それぞれの数值解析モデルを示した。なお, [Case1] のみ, 階高に応じて，柱を数部材に等分割して節点を設けた。

\section{1 柱の細長比が異なる骨組}

幾何形状の異なる骨組として, 柱の細長比入をパラメータとし, 細長比 $\lambda$ (階高 $L_{c}$ ) を, $22(2.5 \mathrm{~m}), 30(3.5 \mathrm{~m}), 60(7.0 \mathrm{~m}), 78(9.0 \mathrm{~m})$, $99(10.5 \mathrm{~m}), 134(14.0 \mathrm{~m})$ と変化させる。 基本モデル $\left(L_{c}=3.5 \mathrm{~m}\right)$ は, $\lambda=30$ である.

初期荷重（長期荷重）時に，これらの骨組の柱に生じる圧縮応 力度は $92.6 \mathrm{~N} / \mathrm{mm}^{2}$ である。 $\lambda=134$ の場合, 長期計容圧縮応力度は $52.2 \mathrm{~N} / \mathrm{mm}^{2}$ となり, 長期荷重を長期許容応力度で除した検定比は 1 以下を満足しない。一方， $\lambda=99$ の場合，検定比は $0.77 て ゙ あ り ， \lambda \leqq$ 99 の骨組は検定比 $\leqq 1.0$ を満足する。なお，基本モデルにおける検 定比は 0.54 である。

図 12 に解析結果を示す。（a）は，載荷点の荷重一変位関係である. $\lambda$ が 22,30 の場合, 最大荷重以降の耐力劣化の度合いが他に比べて 大きい.また, 荷重は最大値を示した後, 直ちに耐力劣化する。一方, $\lambda$ が 60 以上の場合, 荷重一変位関係に急激な耐力劣化は見られない.

(b) は最大荷重と細長比の関係を示す。柱の細長比が大きくなるに 連机て最大荷重が低下するが，荷重は $179.6 \mathrm{kN}$ から $150 \mathrm{kN}$ の範囲 に納まっている.

解析から得られた骨組の最大荷重と, 崩壊機構から算出される最 大荷重を比較する。問題を単純にするため, 載荷構面を取り出した 平面骨組を考元る，大変形時には，梁の変形により柱が内側に引き 込まれる変形を示す。この場合柱の曲げ変形が顕著で，梁両端部の 拘束度は小さく，梁両端部は塑性化しているとは考元にくい。この ことから，平面骨組の梁崩壊機構ではなく，単純梁中央にヒンジが 形成される崩壊機構を想定すると，その崩壊荷重は $189 \mathrm{kN}$ （図中 上実線）である。一方，梁の横座屈変形が進行し，梁中央に大きな ねじれ回転が生じている場合，梁は鉛直荷重によって弱軸曲げを受 けることになる。このことを考虑して，梁中央のヒンジモーメント を弱軸に関する全塑性モーメントとした場合の崩壊荷重は, $119 \mathrm{kN}$ (図中下実線)である。立体骨組解析から得た最大荷重（179.6kN） は，単純梁中央に強軸曲げのヒンジが形成されるときの崩壊荷重 $(189 \mathrm{kN})$ 以下であり，立体骨組においては，平面の崩壊機構から算 出された予想荷重が最大荷重を下回る可能性がある。一方，梁の横 座屈変形が進行したとして, 梁中央の全塑性モーメントを弱軸回り の全塑性モーメントとして算定した場合の崩壊荷重（119kN）は, 数值解析から得られた最大荷重よりも低い.

また，文献 13）には，平面単層門形ラーメン骨組の座屈荷重を算 定するため, 柱頭に荷重を受ける骨組の柱材の座屈長さ係数の表が 揭載されており, この座屈長さ係数を表から求め, 座屈荷重を算定 する方法を示している。この座屈長さ係数は, 梁と柱の剛度によっ て求めら水る。詳細については, 文献 13）を参照頂きたい。解析対 象とした骨組について, 文献 13)の表を用いて座屈荷重を算定すると, 節点が移動しない場合は $93,120 \mathrm{kN}$ となり，節点が移動する場合は $22,320 \mathrm{kN}$ となる。載荷構面のみの平面骨組を考元，解析から得ら水

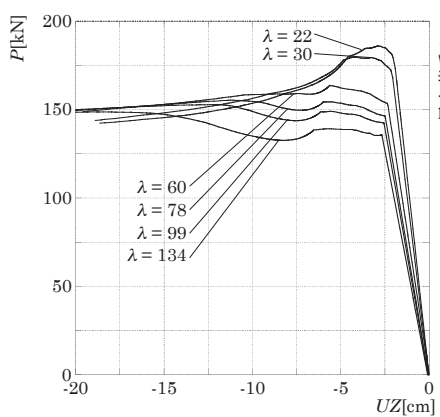

（a）載荷点の荷重-変位関係

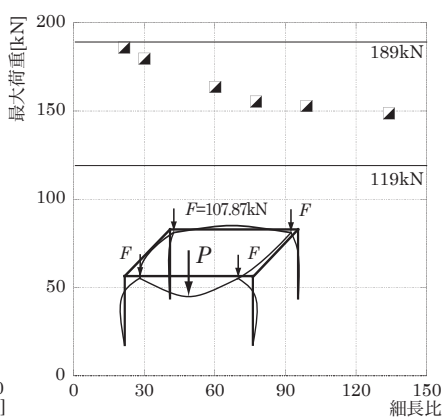

(b) 最大荷重-細長比関係

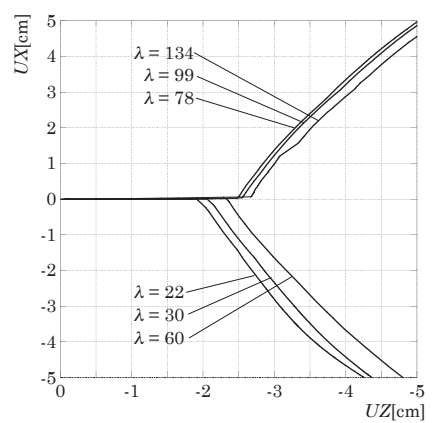

（c）載荷点の面外変位-たわみ関係
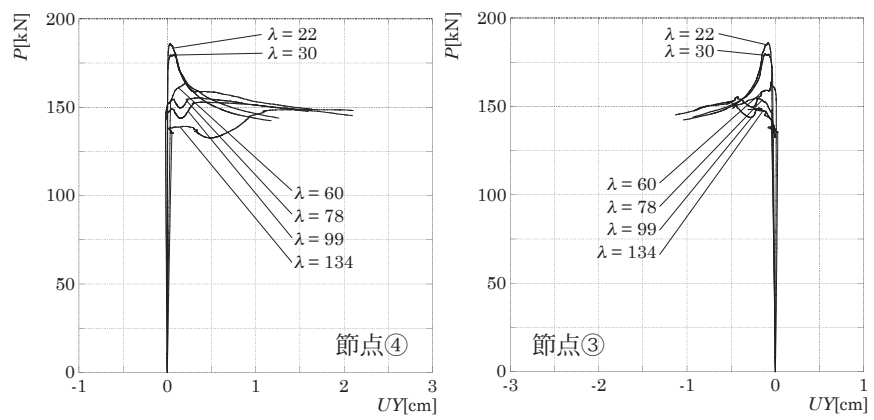

（d）節点(3)・ (4)の荷重-変位関係

図 12 [Case1] の解析

た梁中央の最大荷重（179.6kN）と固定荷重（107.87kN）を加えた 荷重が骨組の座屈荷重（395.34kN）だと考えると，文献 13）から算 出した単層門形ラーメン平面骨組の座屈荷重 $(93,120 \mathrm{kN})$ は十分高

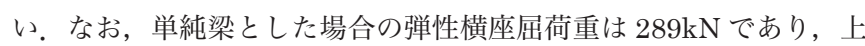
記の崩壊荷重より高い.

(c) は載荷点の面外への横方向変位とたわみの関係である。いずれ の骨組も面外変形を明確に生じ，その開始点は，載荷梁のたわみが およそ $2 \sim 2.5 \mathrm{~cm}$ の時である。これは，スパンの $1 / 350$ 程度の変形 であって，鋼構造における梁のたわみ制限の 1/300よりも小さい. この後, 梁の面外変形が急速に進展し, 横座屈が発生したことがわ かる，横座屈発生後，(a)における荷重-変位関係はいくらかの荷重 増加はあるものの, 面外変形が顥著になり, その後荷重が減少し始 める。これは，梁中央に過荷重を受ける骨組の崩壊に関して，横座 屈が起因していることを示している.

(d) は，荷重と載荷梁両側の節点(3)と (4)について載荷構面内の水平 変位を描いたものである，骨組に明確な sway は生じず，梁中央の載 荷によって，両側節点の柱が内側に引き込まれている。

\section{2 荷重に偏心がある骨組}

次に，荷重の偏心による挙動の変化を検討する，梁中央からの荷 

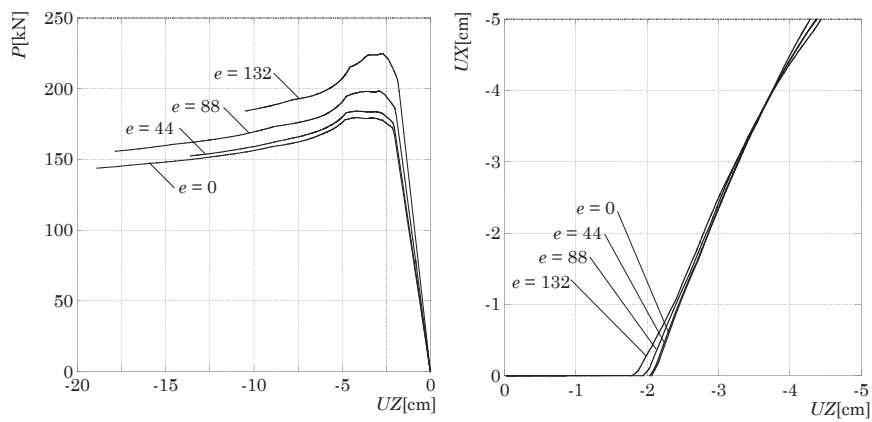

（a）載荷点の荷重-変位関係

(b) 載荷梁の面外変位一たわみ関係
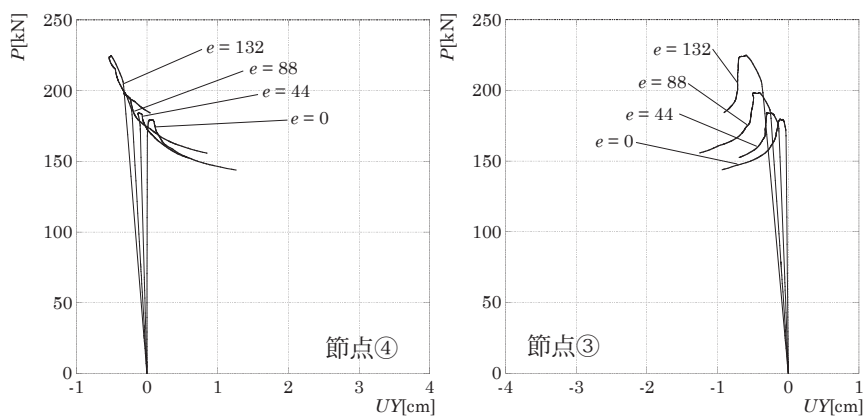

（c） 節点(3) ・ (4)の荷重-変位関係

図 13 [Case2] の解析

重の偏心距離 $e$ をパラメータとする。 $e$ は，スパン $L_{b}$ を用いて $L_{b} / 16$ $(44 \mathrm{~cm}), L_{b} / 8(88 \mathrm{~cm}), 3 L_{b} / 16(132 \mathrm{~cm})$ と変化させる.

図 13 に解析結果を示す。(a) から偏心距離の増加に伴って最大荷 重が増加することがわかる. 最大荷重は, $e=132$ の偏心によって $25 \%$ 増加した。

(b) は，載荷点の面外への横方向変位とたわみ（1/140まで）を描 いたものである。梁の横座屈による面外変形が明膫に生じるのは, たわみがおよそ $2 \mathrm{~cm}$ の頃である，先の細長比をパラメー夕とした解 析と同様の傾向である。一端，横座屈が生じると，たわみの増大と ともに面外変形も増大する。この傾向は, 荷重偏心による違いはない.

（d）には，荷重と載荷梁の両側節点(3)と(4)について載荷内の水平変 位を描いている，最大荷重以前では，swayを生じょうとしている様 子が見受けられるが, 最大荷重以降は, 柱が内側へ引き込まれてい く様子が描かれている，e=132では, 節点(4)の変位に戻りを生じ最 終的に柱が引き込まれている.

\section{5. まとめ}

鋼構造立体ラーメン骨組に対して，小型骨組模型実験と数值解析 を行った。そこで得られた成果は，以下のようになる。

[1] 数值解析に使用した解析コード FERT-3P は, 過荷重を受ける 小型骨組模型実験の最大荷重をほぼ予測可能である。また，立 体骨組が示す不安定挙動をおおむね追跡できる.

[2] 最大荷重は載荷梁の横座屈に支配され，梁のねじれによって決 まる。

次に, 数值解析によって, 骨組の幾何形状（柱の細長比）や荷重 の偏心によって不安定挙動はどのように変化するかを調べた結果, 以下の知見を得た。梁 1 力所に鉛直過荷重を受ける鋼構造単層立体
ラーメン骨組について,

（1）崩壊挙動は，載荷梁の横座屈によって支配される。

（2）柱の細長比の大きい骨組に対して，最大荷重は，平面単純梁 の載荷点に強軸曲げによるヒンジが形成されるときの崩壊荷重 值に達せず，弱軸に曲げを受けると考えた場合との中間の值と なる。

（3）柱の細長比によらず，載荷構面においては，柱の引き込み変 形が支配的で，明確な sway は生じない.

（4）荷重の偏心によって，最大荷重は増加する.

（5）荷重の偏心がある骨組についても最大荷重は，載荷梁の横座 屈によって支配される。

\section{謝辞}

本研究は, 社団法人日本鉄鋼連盟・2007 年度「鋼構造研究・教育 助成事業」による一般研究助成「鉛直過荷重時における立体ラーメ ン骨組の性能評価法」(研究代表者：金尾伊織）の助成を受けた。

試験体，材料試験片および載荷治具の製作にあたっては，京都工 芸繊維大学ものづくり教育研究支援センターの技術職員の皆様に多 大なるご協力とご助言を頂きました，材料試験では，京都工芸繊維 大学高度技術支援センター技術職員の小山清司，四方利和の両氏に 協力を得ました。また，小型立体骨組実験では，京都工芸繊維大学 大学院生の嶋瀬裕之, 清水由起, 小谷俊二, 伊藤俊一の諸氏に大変 お世話になりました。ここに感謝して御礼申し上げます。

参考文献

1) 小河利行, 桑田真理子: 鉛直荷重を受ける剛接合単層ラチスドームの 弹塑性座屈性状，日本建築学会構造系論文集，第 506 号，pp.131-138， 1998.4

2）小河利行, 加藤史郎, 五十畑徹, 熊谷知彦: 荷重不整および形状初期不整 を有する単層 HP シェルの座屈挙動と荷重評価，日本建築学会構造系論文 集，第 560 号，pp.139-145，2002.10.

3）倉橋 勲，苫米地司，永田 薰，吹原正晃，田邊進一，本田明弘：多 雪区域の建設される大規模構造物の積雪荷重の検討，構造工学論文集， Vol.44B, pp.95-100, 1998.3.

4） 中村恒善，太田 修，上谷宏二 : 鋼骨組の腰くびれ横摇れ崩壊に関する実 験的研究，日本建筑学会論文報告集，No.315，pp.48-60，1982.5

5） 中村恒善, 石田修三, 太田 修:サブアッセンブリッジの過大な変形によっ て誘発される骨組の全体的崩壊挙動，第 24 回構造工学シンポジウム論文 集，pp.101-107，1978.2.

6）村本 真, 岩本圭悟, 金尾伊織, 森迫清貴 : 鋼構造立体剛接骨組の過荷重 時臨界挙動の解析，構造工学論文集，Vol.53B，pp.277-282，2007.3。

7) 金尾伊織, 森迫清貴, 中村 武：一軸材料線要素からなる梁 - 柱有限要素 を用いた鋼立体ラーメンの弹塑性挙動の解析，日本建築学会構造系論文集， 第 533 号，pp.99-106，2000.7.

8) 藤本盛久, 松本芳紀 : 鋼構造骨組の三次元弾塑性挙動に関する研究 その 1 ・三次元鋼構造骨組の骨組実験，日本建築学会論文報告集，第 244 号， pp.41-49, 1976.6 .

9）金尾（奥田）伊織，森迫清貴，中村美保，石田修三：弾性立体ラーメンの 大たわみ挙動の解析と検証実験，日本建築学会構造系論文集，第 510 号， pp.115-121, 1998.8,

10) 金尾（奥田）伊織，森迫清貴，中村 武：一軸材料線要素からなる梁-柱 有限要素を用いた $\mathrm{H}$ 型鋼梁の弾塑性横座屈挙動の解析，日本建築学会構 造系論文集，No.527，pp.95-101，2000.1.

11）金尾伊織，中島正愛，劉 大偉：繰り返し載荷を受ける $\mathrm{H}$ 形鋼梁の横座 屈挙動と横座屈補剛，日本建築学会構造系論文集，No.544，pp.147-154， 2001.6.

12）森迫清貴，西村 督，金尾（奥田）伊織，門藤芳樹：立体骨組の大たわみ 弾塑性解析，最近の建築構造解析理論の基礎と応用，日本建築学会，応用 力学シリーズ 11 , 第 2 章, pp.33-64, 2004.5.

13）日本建築学会：鋼構造座屈設計指針，2 章，p.31，1996.1,

14）藤井大地：EXCEL で解く 3 次元建築構造解析，丸善，2005.2. 